\title{
Pequena imprensa em disputa: uma análise dos jornais Folha de Ituiutaba e do Correio do Triângulo (1964) ${ }^{1}$
}

Caio Vinicius de Carvalho FERREIRA²

Resumo:

Em 1964, com o golpe civil-militar, no pontal do Triângulo Mineiro o jornal Folha de Ituiutaba, por conta de sua linha editorial, foi perseguido e fechado. Logo após esse fechamento, ressurgiu um jornal local que já havia circulado na região anos antes, o Correio do Triângulo, que retorna como um apoiador das mudanças políticas que aconteceram com a tomada do poder. Este trabalho se propõe a analisar os dois periódicos e entender a luta pela hegemonia política em suas páginas.

Palavras-chave: Pequena imprensa. Golpe de 1964. Pontal do Triângulo Mineiro.

\section{Small press in conflict: an analysis of the Folha de Ituiutaba and Correio do Triângulo newspapers (1964)}

\begin{abstract}
:
In 1964, with the civil-military coup, in the point of the Triângulo Mineiro, the newspaper Folha de Ituiutaba, by its editorial line, was persecuted and closed. Soon after that, a local newspaper that had been circulated in the region years earlier, Correio do Triângulo, returns as a supporter of the political changes that took place with the seizure of power. This work intends to analyze both newspapers and understand the struggle for political hegemony in its pages.
\end{abstract}

Keywords: Small press. 1964 Coup. Pontal do Triângulo Mineiro.

\section{Prensa provincial en disputa: un análisis del periódico Folha de Ituiutaba y del Correio do Triângulo (1964)}

\begin{abstract}
Resumen:
El 1964, con el golpe civil-militar, en la región del Pontal do Triângulo Mineiro, el periódico Folha de Ituiutaba, por su líena editorial, fue perseguido y cerrado. Logo después, resurgió un periódico regional que había circulado previamente, el Correio do Triângulo, que vuelve como partidario de los cambios políticos ocurridos con la toma del poder. Así, se propone en este trabajo analizar los dos periódicos y comprender la lucha por la hegemonía política en sus páginas.
\end{abstract}

Palabras clave: Prensa provincial. Golpe del 1964. Pontal do Triângulo Mineiro.

\footnotetext{
${ }^{1} \mathrm{O}$ presente artigo é fruto de parte da dissertação intitulada Política, imprensa local, perseguição: o golpe de 1964 no Pontal do Triângulo mineiro, defendida em fevereiro de 2017. A pesquisa teve financiamento integral da Coordenação de Aperfeiçoamento de Pessoal de Nível Superior (CAPES).

${ }^{2}$ Graduado em História pela Universidade Federal de Uberlândia (UFU), mestre e doutorando pelo Programa de Pós-Graduação em História da Universidade Federal de Uberlândia (PPGHI/UFU). E-mail: caiovdecferreira@gmail.com
} 
Introdução

Em 1964 ocorreu um golpe de Estado no Brasil no qual as forças armadas, em conjunto com uma parcela da população, tomaram os cargos políticos e instauraram um governo autoritário. No interior de Minas Gerais, na microrregião do Pontal do Triângulo Mineiro, na cidade de Ituiutaba, o golpe civil-militar se fez sentir em forma de intervenção. A chegada de uma junta militar, em cooperação com civis no município, fechou um jornal local, a Folha de Ituiutaba, e impediu sua circulação, culminando na prisão do proprietário e de seu redator chefe, que foram levados ao Departamento de Ordem Política (DOPS), em Belo Horizonte (ARQUIVO PÚBLICO MINEIRO-Fundo DOPS/MG, rolo 049, pastas 3882-im.11).

Essa junta militar também forçou a renúncia do prefeito, do vice e de mais cinco vereadores da cidade, todos ligados às políticas trabalhistas, em sua maioria, filiados ao Partido Trabalhista Brasileiro (PTB). Em seus lugares foi colocado outro grupo político, ligado ao diretório local da União Democrática Brasileira (UDN). A aliança ainda possibilitou a perseguição a líderes sindicais locais, desarticulando o recém-fundado Sindicato dos Trabalhadores Rurais de Ituiutaba (ARQUIVO PÚBLICO MINEIROFundo DOPS/MG, rolo 049, pastas 3882-im.3). Os eventos persecutórios desencadeados, na esfera nacional, logo no início do regime militar ficaram conhecidos como parte da “Operação Limpeza”, ação que buscou neutralizar qualquer forma de oposição ao golpe que poderia se sustentar nesse primeiro momento do regime autoritário (ALVES, 1989).

Nesse contexto, ressurge um jornal que já havia circulado na região, o Correio do Triângulo, que retorna como porta-voz de um novo grupo que conquistou a hegemonia política local no processo, passando a ser um veículo de comunicação representativo de ideais anticomunistas e alinhado com o discurso da UDN e dos militares.

Os dois periódicos seguiam o padrão de jornais do interior, ou seja, eram voltados prioritariamente para assuntos regionais. Os impressos publicavam notas sobre as cidades em que circulavam, principalmente as localizadas no Pontal do Triângulo Mineiro e no entorno, dando ênfase às notícias da cidade de Ituiutaba, mas traziam também notícias diversas de cunho nacional e estadual, muitas das vezes transpostas de outros periódicos.

Segundo Capelato (1988, p.13), desde “os seus primórdios, a imprensa se impôs como uma força política. Os governos e os poderosos sempre a utilizam e temem; por isso adulam, vigiam, controlam e punem os jornais". Muitos jornais foram censurados, fechados e/ou perseguidos no Brasil republicano, principalmente durante as ditaduras 
ocorridas no século $\mathrm{XX}^{3}$. Entretanto, apesar da proeminência de estudos sobre os jornais e outros periódicos em períodos autoritários nas últimas décadas, ainda são escassas as pesquisas voltadas a compreensão de processos em contextos que se encontram à margem. Existe, no mercado acadêmico e editorial, um número satisfatório de estudos sobre a participação política (como aliadas ou oposicionistas) dos jornais, principalmente referindo-se à chamada grande imprensa e à imprensa alternativa. Porém, ainda engatinham os estudos que se referem à pequena imprensa.

A denominação pequena imprensa ou imprensa local e regional aqui utilizada se refere a jornais de cidades pequenas e de médio porte, que possuem suas manchetes e circulação quase restritas à região onde são produzidos. A denominação constitui-se em contraposição à noção que usamos de grande imprensa, que é designada aos jornais com altos números de tiragem e de circulação (ASSIS, 2013). Para o autor, o termo remete às mídias fora das capitais e que estão situadas na parte interna dos estados, vocacionadas mais em noticiar o cotidiano e a vida das comunidades locais do que para o país ou para o mundo.

Há um grande número de jornais fechados pelo golpe de 1964. Por exemplo, $O$ Binômio, jornal de sátira e crítica política produzido em Belo Horizonte; O Semanário, jornal estritamente de orientação nacionalista; Brasil Urgente, informativo católico; Panfleto, jornal da Frente de Mobilização Popular; Política Operária, tabloide da Nova esquerda; os semanários clandestinos Novos Rumos e A Classe Operária, ligados ao Partido Comunista Brasileiro (PCB); A Liga, do movimento das Ligas Camponesas. Todos esses jornais são uma alternativa ao que conhecemos como grande imprensa e muitos deles foram o embrião do que viria a ser conhecido como imprensa alternativa (KUCINSKI, 2001).

A mídia não é isenta de tensões e desempenha papel fundamental em prol dos interesses de grupos que lutam pela hegemonia política. Muitas das vezes não cumpre somente um papel de vigilância, mas, sim, de cumplicidade política. Por outro lado, os jornais são empresas e, como tal, buscam o lucro. Os jornais negociam um produto muito especial, pois são capazes de formar opiniões, estimular comportamentos e ações políticas, ou seja, "se limitam a apresentar o que aconteceu, mas selecionam, ordenam, estruturam e narram, de uma determinada forma, aquilo que elegem como fato digno de chegar até o público" (MARTINS; LUCA, 2006, p.11). O historiador deve, portanto, ter

\footnotetext{
${ }^{3}$ Estado Novo (1937-1945) e Ditadura Militar (1964-1985).
} 
ciência de que um periódico, independentemente de seu perfil, está envolvido no jogo de interesses e tramas, com suas contradições e tensões, ora conflitantes, ora convergentes.

Os jornais são produtos feitos a partir de representações contextualizadas na realidade, o que, de certa forma, representa formas simbólicas de luta pelo poder de representar, afirmando-se como porta voz de grupos, de memórias, de ideais ou de partidos políticos. É importante, portanto, “identificar o modo como em diferentes lugares e momentos uma determinada realidade social é construída, pensada, dada a ler" (CHARTIER, 1990, p. 17). As representações são compreendidas como classificações e divisões que organizam a assimilação do mundo como categoria de apreensão do real. Desse modo, o ausente é substituído por uma imagem que, por sua vez, se constituirá em uma memória. Assim, as representações devem ser pensadas sempre no campo das concorrências e competições por hegemonia, poder e dominação (CHARTIER, 1990).

A imprensa local não só foi importante dentro do processo político do golpe de 1964, na microrregião, como foi um dos seus protagonistas. Por tal razão, procuramos analisar os periódicos selecionados e como se comportaram durante esse processo político. Como metodologia, nos apoiamos em Luca (2010), quando afirma que ao analisarmos fontes impressas, devemos atentar para a materialidade e para os suportes do periódico Devem ser observados o formato de impressão, o papel, a tinta, o tamanho das letras, as manchetes, a presença/ausência de imagens, número de páginas, separação das folhas, capa, corpo documental, estruturação e divisão de conteúdos, funções e articulações com a sociedade, periodicidade, o tempo e o espaço em que se insere o jornal, relação com o mercado, os anúncios e publicidade, o meio de sobrevivência financeira, o seu público e seus objetivos. Com isso, levam-se em conta as funções sociais do impresso. Há uma importância em identificar quem são os sujeitos responsáveis pela linha editorial, os colaboradores mais assíduos e atentar para os títulos e textos. Inquirir, também, sobre a sua relação com os poderes políticos institucionais ou não, bem como seus interesses financeiros (LUCA, 2010).

Para isso, analisamos edições dos jornais Folha de Ituiutaba (de 1962 até 1964, no total de 164 edições) e Correio do Triângulo (60 edições publicadas entre 1964 e 1965), principalmente observando as notas de teor político dos jornais. Empenhamo-nos em problematizar a linguagem desses impressos, como material escrito, dialogando com a complexidade do desenho ou identidade visual, pois a análise dos projetos editoriais da Folha de Ituiutaba e do Correio do Triângulo nos demonstra suas propostas como periódicos. 


\section{A Folha de Ituiutaba}

O jornal Folha de Ituiutaba circulou entre 1942 e 1964 e, ao longo desse tempo, passou por diversas modificações em sua linha editorial. $O$ jornal foi fundado em 4 de julho de 1942, por Ítalo Géntil, e em 1946 a Folha foi adquirida por Ercílio Domingues da Silva, que seguiu como diretor do jornal até seu último dia de circulação. Em 1951, Ercílio procurava um novo redator-chefe para o jornal, contratando o jornalista Geraldo Sétimo Moreira. No início dos anos 1960, o nome de Manoel Agostinho passou a integrar o cabeçalho como redator. Esse trio de jornalistas seguiu como os principais nomes do jornal na década de 1960 até seu fechamento. Entretanto, a Folha ainda tinha outros importantes colaboradores, que escreviam constantemente em suas páginas.

Pode ser destacada a Coluna Sindical, escrita pelo alfaiate e sindicalista Ivanildo Francisco dos Santos, que estreou em 18 de agosto de 1962. A coluna tinha como objetivo

[...] prestar esclarecimento aos trabalhadores sindicalizados desta cidade, bem assim propugnar por uma vida sindical mais ativa, capaz de elevar sempre o nível associativo dos empregados no comércio, dos condutores de veículos rodoviários e dos oficiais de alfaiate e costureiras (SANTOS, 1962, p. 1).

Ivanildo também publicava na seção Legislativo em ação, onde comentava os lances políticos da Câmara Municipal de Ituiutaba e o seguimento das leis, aprovações e negações que ocorriam no Poder Legislativo da cidade. Os advogados Humberto Teodoro Gomes e Tomaz de Aquino Petraglia também contribuíam para o jornal durante a década de 1960, trazendo diversos escritos de cunho nacionalista.

Em relação às notícias nacionais e estaduais, a Folha tinha como referência outros jornais e emissoras de rádio, pois os "repórteres de cidades com apenas um jornal precisam se manter apenas à frente da televisão e dos serviços telegráficos, que representam outros tipos de informação e não constituem uma verdadeira concorrência" (DARNTON, 1990 p. 85).

Produzido e entregue duas vezes na semana, o impresso contava geralmente com quatro páginas - a não ser em edições especiais e comemorativas, em que ampliava esse número, podendo chegar a 20 -, e apesar de tratar, de maneira quase essencial, sobre assuntos da região, o jornal era distribuído em todo o Triângulo Mineiro, oeste de Minas Gerais, parte dos estados de Goiás e de São Paulo, chegando, nos seus últimos anos de trajetória, a ter uma tiragem de 3.000 exemplares por edição. O jornal era impresso somente com a tinta preta, seguindo o padrão de um jornal em tamanho "grande", com 
suas páginas tendo cerca de 53,5×36 cm, configurando-se como um jornal perto do formato conhecido como broadsheet ${ }^{4}$.

O jornal possuía algumas imagens. Havia poucas fotos e gravuras, e, quando apareciam, estavam apenas nas primeiras páginas, sendo, em sua maioria, de propagandas e anúncios. A Folha vivia à custa não só das vendas das suas edições, mas também de anúncios e propagandas que lotavam suas páginas. Nesse sentido, podemos dividir as propagandas do jornal em três eixos distintos: anúncios de produtos vendidos nacionalmente, principalmente ligados ao ramo automobilístico; anúncios locais, de lojas, empresas e serviços de trabalhadores liberais; e, por fim, as vendas de propriedades imobiliárias que compunham a estrutura do município.

O jornal, por ter sobrevivido por 22 anos, conquistou um bom número de leitores, diferente dos outros periódicos locais, que duravam pouco tempo. Como nos afirma Galves (2004), as relações políticas que dão as características dos espaços em que circulam periódicos da "pequena imprensa" se compõem de variáveis que precisam ser consideradas, como o comportamento eleitoral, a tradição política de quem ali escreve, as relações com as lideranças políticas locais e regionais, além das ações/reações perante os acontecimentos estaduais e nacionais.

Ressaltamos o posicionamento político dos três jornalistas da Folha, que eram formalmente filiados ao Partido Social Democrático (PSD). Uma famosa reflexão nas ciências políticas propôs o questionamento se “Jornais são Partidos?”, e, apesar de não serem, muitas vezes se confundem, pois se "os partidos são de opinião, os jornais também são de opinião, nada de surpreendente se estes às vezes se comportam como aqueles" (WEFFORT, 1984, p. 39).

Apesar dos jornalistas serem pessedistas, há nas páginas do jornal um claro apoio às medidas tomadas no poder municipal e às ações em favor dos trabalhadores no Legislativo, tornando-se porta-voz das ações do prefeito petebista. Assim, o jornal, em 1962, comemora com o editorial "Conquistou o PTB (por fim) a prefeitura de Ituiutaba" (CONQUISTOU..., 1962, p. 1).

Em 19 de janeiro de 1963 é registrado na Coluna Sindical um encontro na Câmara Municipal entre o prefeito petebista eleito José Arcênio, o vice e os trabalhadores municipais, em que o prefeito esclarece seus pontos de vista sobre os direitos trabalhistas

\footnotetext{
${ }^{4} \mathrm{O}$ formato Standard (que também é conhecido como Broadsheet), é uma brochura de padrão "grande", no qual suas páginas têm aproximadamente entre $53,5 \times 36 \mathrm{~cm}$, caracterizando-se por páginas longamente verticalizadas e em geral dobradas horizontalmente no meio (DAMASCENO, 2013).
} 
e se posiciona a favor da "Regulamentação definitiva do salário mínimo", afirmando que o " $13^{\circ}$ salário foi igualmente objeto de consulta em reais possibilidades de aprovação" para os trabalhadores do município (SANTOS, 1963, p. 1). A coluna, durante várias edições, apoia os trabalhadores da Prefeitura a reivindicarem esses direitos, chegando a propor uma greve (SANTOS, 1963).

Encontra-se também nas folhas do jornal o título "Legislação Trabalhista (salário mínimo, etc.) para os trabalhadores municipais", que nada mais é que uma entrevista inaugural da nova gestão de José Arcênio, na qual o recém-empossado no executivo afirma suas propostas para os trabalhadores do município (ARCÊNIO, 1963, p. 1). Outro artigo do ano anterior tem em seu título "Prefeitura de BH vai pagar $13^{\circ}$ salário a seus servidores", dizendo que essa ação deveria servir de exemplo (PREFEITURA..., 1962, p. 1). Por fim, em 1964, o jornal anuncia: “13 Salário: Prefeitura começou a pagar”, notícia de que, por determinação do prefeito em exercício, iniciou-se o pagamento relativo a 1963 aos servidores municipais (13 SALÁRIO..., 1964, p. 1).

O jornal também se posicionou a favor da aplicação da "Semana Inglesa", proposta que diminuiu a carga horária dos trabalhadores da indústria e comércio local. Logo no início de 1963, o jornal comemora a nova instalação da Câmara Municipal com uma nota em destaque na primeira página, que dizia: “A Semana Inglesa vem aí!” (A SEMANA..., 1963, p. 1). Semanas depois, ainda havia uma cobrança nas folhas do jornal, dizendo: "Ituiutaba quer a Semana Inglesa!” (ITUIUTABA..., 1963, p. 1). Por fim, o jornal anuncia a notícia em sua primeira página, da seguinte forma: "Câmara aprovou instituição da Semana Inglesa" (CÂMARA..., 1963, p. 1).

A Folha saiu em favor da proposta do executivo para um novo código tributário, assim noticiado: "Votação do Código tributário provocou renúncia do presidente" (VOTAÇÃO..., 1963, p. 1). O texto denunciava a artimanha de alguns vereadores, principalmente udenistas, para barrar a votação do novo código de tributos que aumentaria a taxa de impostos das propriedades rurais proporcional ao tamanho. $\mathrm{O}$ artigo "Leis Trabalhistas para o trabalhador Rural", sobre a lei do "Estatuto do trabalhador rural", confirmou novos direitos aos trabalhadores, a partir do qual ficariam "abolidos os velhos costumes, tradições e os sistemas empíricos de trabalho predominantes no meio rural, entre empregado e empregador" (LEIS..., 1963, p. 1).

Ivanildo chefiava o Sindicato dos Alfaiates da cidade e se tornou diretor da Associação dos Trabalhadores de Ituiutaba em abril de 1963. Em janeiro de 1964, junto a outros trabalhadores, fundou o Sindicato dos Trabalhadores Rurais de Ituiutaba. Na sua 
coluna, Ivanildo trazia trechos como forma de conscientização sobre novos direitos trabalhistas, dentre esses, podemos citar: "Util e proveitoso trabalho: Procedida a identificação e a entrega de cadernetas profissionais aos trabalhadores de Ituiutaba" (SANTOS, 1962, p. 4); "Esclarecimentos sobre o salário mínimo" (SANTOS, 1963, p. 4). Assim, a Coluna Sindical se configurou como um importante instrumento de mobilização dos trabalhadores.

A Folha articulou, por meio dos seus escritos, a formação do Sindicato dos Trabalhadores Rurais de Ituiutaba, quando o jornal foi um importante espaço de informação dos encontros que aconteceriam na cidade, como maneira de agrupar os trabalhadores. Em notícia na primeira página, diz: "Vai começar a sindicalização rural". Com isso, a notícia afirma que o redator-chefe do jornal dispunha de instruções para a formação do sindicato na cidade (VAI..., 1963, p. 1). Na primeira edição de 1964, na sua primeira página, a Folha anuncia a fundação do Sindicato dos Trabalhadores Rurais de Ituiutaba, que aconteceu em assembleia no dia 19 de janeiro na Câmara Municipal.

É quase consenso na historiografia que a maioria da imprensa, principalmente o que conhecemos como grande imprensa, não só foi contra o governo de João Goulart como também ajudou a desestabilizá-lo (CAPELATO, 1988). Esse não foi o caso da Folha de Ituiutaba. O jornal se mostrou como um apoiador do governo de João Goulart e também das suas medidas, como as Reformas de Base, em especial da Reforma Agrária. Afirmava a Folha: “OS PRESIDENTES nacionais do PSD, da UDN e do PSP já tomaram posição ostensiva contra as Reformas de Base. Querem que tudo continuem como está para ver o que fica, sem se importar com a brisa que anuncia a tempestade" (OS PRESIDENTES...1962, p. 4). Também nos editoriais "Reforma Agrária e Gorilas conservadores" (REFORMA..., 1963, p. 4) e "Reformas: única solução" (REFORMAS..., 1963, p. 1), e, ainda, nos textos "Necessária a Reforma Agrária, segundo o Censo Agrícola" (NECESSÁRIA..., 1963, p. 4) e "Fazendas de Jango também vão entrar na reforma" (FAZENDAS..., 1963, p. 2). O jornal se posicionou claramente favorável em relação às Reformas de Base no editorial "De como fazer omelete sem quebrar o ôvo", afirmando que "Nêsse assunto de reformas de base - Reforma Agrária, sobretudo - temos nossa posição definida. Propugnamos por elas e apoiamos a proposta do Govêrno da União por sua consecução" (DE COMO..., 1963, p. 4).

No jornal há dois colunistas que merecem nossa atenção. São os advogados Humberto Teodoro Júnior e Thómaz de Aquino Petraglia. Seus artigos, declaradamente de cunho nacionalista, apareciam esporadicamente nas páginas da Folha, como "Os 
empréstimos norte-americanos" (TEODORO JÚNIOR, 1963, p. 4), em que condenava os empréstimos dos Estados Unidos (EUA) ao Brasil e a dívida e dependência criada deles, e "Testemunhos Nacionalistas" (PETRAGLIA, 1963, p. 4), no qual afirma a importância das Reformas de Base como um movimento libertador do país em relação à dependência de outros países.

Segundo Moreira (1998), o ideário nacionalista, centrado no conceito de autossustentabilidade, concentrou-se em duas correntes preponderantes na metade do século XX: o nacional-desenvolvimento, de caráter liberal, preocupada com a modernização, e o nacionalismo econômico, que era a vertente defendida pelas esquerdas, ligada aos interesses populares, característica de socialistas, trabalhistas e comunistas. Essa segunda corrente é a que encontramos nas páginas da Folha. Conforme aponta a autora, o nacionalismo como ideologia de Estado, característico dos anos 1930-1964, ancorou-se não só ao populismo de Getúlio Vargas, mas também ao desenvolvimentismo de Juscelino Kubitschek e ao reformismo social de João Goulart. Assim, na "prática, defender o desenvolvimento autossustentado significava, em primeiro lugar, criticar o modelo econômico agrário-exportador e, por extensão, a classe social a ele ligada: a oligarquia latifundiária" (MOREIRA, 1998, p. 4). A opção nacionalista se revela com a construção de uma economia autocentrada, voltada para o mercado interno. Nas esquerdas, cresceu um forte antiamericanismo, que identificava os interesses econômicos dos EUA como "imperialismo". Ser nacionalista, portanto, significa ser favorável ao país tornar-se autossustentável, elegendo a oligarquia agrária como representante interna da exploração e do atraso e o imperialismo como fator externo.

Apesar de nos artigos dos dois advogados a questão do nacionalismo se mostrar de maneira mais latente, a linha editorial da Folha em si seguia o ideário nacionalista econômico. Diversos artigos que se encontram no jornal seguem essa linha, como "Capital de maus brasileiros depositados no exterior daria para resolver os problemas do País" (CAPITAL..., 1962, p. 4) e o texto no qual o grupo jornalístico $O$ Globo é chamado de "antinacionalista e entreguista" (TRAPOS...1962, p. 4).

Hippolito (2012) afirma que o PSD era basicamente formado por duas alas que entraram em conflito nos últimos anos de partido. Há a chamada Ala Moça, constituída por jovens, na maioria de orientação reformista/nacionalista, e, por outro lado, o que a autora chama de "raposas", referindo-se a partidários ligados às elites rurais e herdeiros oligárquicos que defendiam os direitos elitistas. A Ala Moça foi uma das fundadoras da Frente Parlamentar Nacionalista (FPN), o que criou conflitos internos no partido com as 
alas ligadas à oligarquia rural. Podemos afirmar que os jornalistas da Folha se aproximam, politicamente, da Ala Moça, por defenderem políticas reformistas, aliandose aos políticos do PTB local que estavam colocando em prática tal defesa, além de defenderem as Reformas de Base.

O grande "crime" da Folha foi ser o porta-voz das esquerdas da microrregião. Nas suas páginas encontramos a defesa de interesses trabalhistas, sindicalistas e nacionalistas. As elites locais viam o jornal como um inimigo que precisava ser derrotado, e o golpe de 1964 foi esse momento. As atividades da Folha foram interrompidas pelo golpe, sendo que nenhuma edição do jornal ocorreu em abril de $1964^{5}$. O jornal, no início desse mês, foi fechado e impedido de circular, e Ercílio e Geraldo (junto a outros que escreviam no periódico) foram perseguidos e presos pela aliança civil-militar.

Figura 1 - Folha de Ituiutaba, n. 1306, 8 fev. 1964, p. 1.

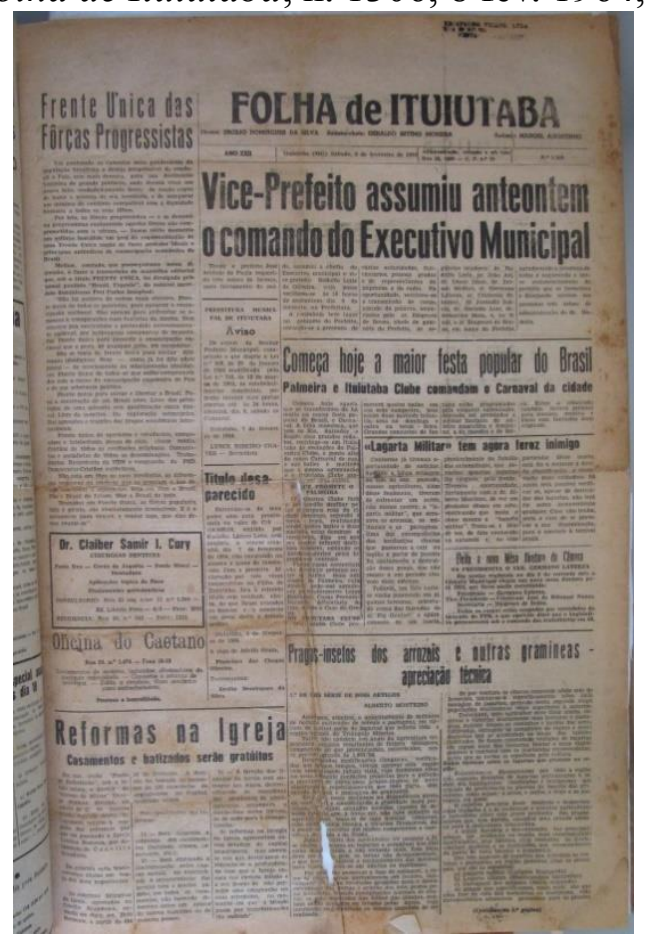

Fonte: Centro de Pesquisa, Documentação e Memória do Pontal (CEPDOMP), Ituiutaba-MG.

\section{O Correio do Triângulo}

Em contrapartida, quase que de imediato ao golpe, um periódico que já havia circulado na cidade nos fins da década anterior voltou à ativa com uma nova roupagem. O jornal Correio do Triângulo retornou como porta-voz tanto dos militares quanto das

\footnotetext{
${ }^{5}$ A última edição encontrada do jornal Folha de Ituiutaba foi a referente à data de 25/03/1964.
} 
elites econômicas e conservadoras locais que estiveram à frente dos atos arbitrários ocorridos.

O Correio não era novidade na cidade e região, pois seus jornalistas eram tão conhecidos quanto os da Folha. Anos antes, em 1959, uma versão do Correio do Triângulo circulou na região. Bandeira (2015), em um estudo sobre essa primeira fase de circulação do Correio que ocorreu entre os meses de fevereiro a setembro de 1959, afirma que o jornal possuía o formato próximo do que se conhece como tabloide, com dimensões $47 x 33 \mathrm{~cm}$, que, comparadas com o tamanho da Folha, eram páginas “pequenas". Uma das hipóteses do fim dessa primeira versão do Correio (da mesma forma que outros periódicos ituiutabanos que também tiveram vida efêmera ao logo do século XX) foi por questões financeiras, já que a região não suportaria mais um impresso, pois a Folha, naquele momento, já se tornara um jornal tradicional e tinha seu público formado (BANDEIRA, 2015).

Figura 2 - Correio do Triângulo, n. 18, 19 mar. 1959, p. 1.

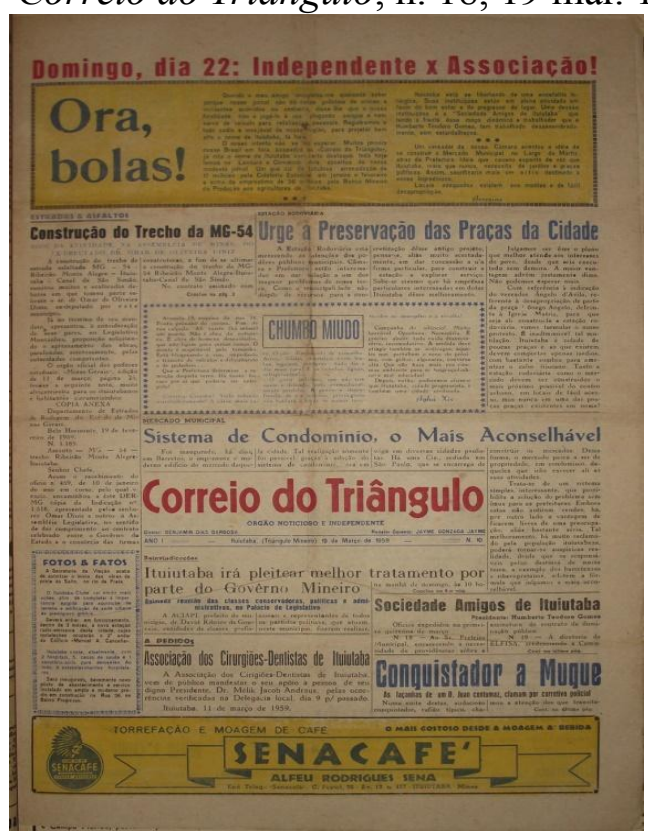

Fonte: Centro de Pesquisa, Documentação e Memória do Pontal (CEPDOMP), Ituiutaba-MG.

O Correio produzido em 1959 tinha um projeto gráfico com temas e questões distintas das que circulariam em 1964, desde seu tamanho até a impressão, que contava com cores e imagens, artifício que não se repete na sua segunda fase. Se comparada com as edições da Folha, nessa versão de 1959 havia muitas imagens, enquanto a Folha contava com mais escritos do que gravuras. Isso demonstra um papel crucial na manutenção do periódico por meio da propaganda, enquanto a Folha provavelmente se 
sustentava por outros meios. Conforme afirma Bandeira (2015), o jornal, em sua linha editorial em 1959, defendia os interesses do setor agropecuário, investindo em forte propaganda sobre as riquezas produtivas rurais do município.

A nova versão do Correio, que passou a circular a partir de abril de 1964, se comparada com a de 1959, ressurgiu mais parecida em sua estética com a Folha do que com o antigo Correio. Inclusive o novo tamanho, que era o mesmo da Folha, configurando o formato de um jornal standard, de modo que suas páginas eram impressas apenas na tinta preta, com poucas imagens, muitas reportagens e colunas.

Durante seus primeiros meses, o jornal circulou sem periodicidade fixa, sendo que, no mês de abril, teve apenas com duas edições. Essa inconstância nas publicações se deu pelo jornal ter iniciado suas atividades em gráfica emprestada, produzido dentro da Associação Rural de Ituiutaba, organização formada por produtores e proprietários rurais, na maioria, latifundiários. O jornal contava com seis páginas, em um primeiro momento. Posteriormente, em agosto de 1964, passou a quatro, a não ser em edições comemorativas, quando podia chegar a até 12 páginas.

Nessa nova empreitada do jornal, assinava o expediente do Correio do Triângulo, como diretor comercial, Joaquin Pires das Neves, e, como redator-chefe, Jayme Gonzaga Jayme. Benjamin Dias Barbosa assinava como secretário. A gráfica Correio do Triângulo $\mathrm{S} / \mathrm{A}$ possuía vários acionistas que assinavam como subescritores, muitos deles ligados à política local, principalmente à UDN. De maneira semelhante à Folha, no Correio havia diversos redatores que colaboravam com variadas colunas, com destaque para Legislativo em Foco, que se dedicava a discutir os entraves no legislativo de Ituiutaba; O pontal em revista, que trazia notícias dos municípios vizinhos; Repórter “ $A$. $Z$.”, que cobria furos locais e passou a circular nas páginas do Correio a partir de 1965; e, também, a Coluna da Associação Comercial e Agropecuária de Ituiutaba (ACIAPI), associação dos proprietários rurais, donos de indústrias e comerciantes da cidade.

As colunas do Correio e da Folha eram bem parecidas em sua estética e também em seus conteúdos. Muitas das que existiam na Folha parecem ter sido transpostas para o Correio, discutindo temas muito similares, desde a agricultura, o futebol local, os entraves do legislativo. Porém, o Correio trazia colunas com temas novos também. 
Figura 3 - Correio do Triângulo, n. 3, 10 maio 1964, p. 1.

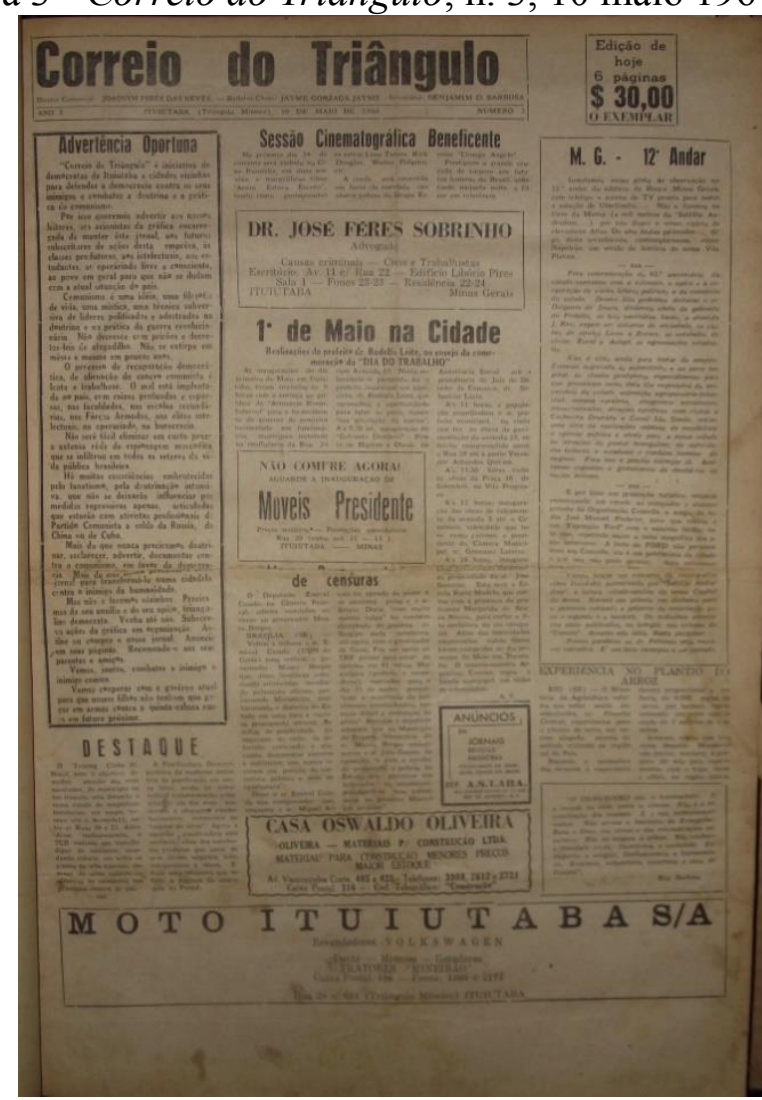

Fonte: Centro de Pesquisa, Documentação e Memória do Pontal (CEPDOMP), Ituiutaba-MG.

Do mesmo modo que a Folha, é possível diferenciar os anúncios encontrados no jornal, basicamente, em três pontos. Os dois jornais (a Folha e a segunda versão do Correio) se assemelhavam nesse ponto. Havia, nas páginas do Correio, anúncios de produtos nacionais, na maioria, automóveis. Em segundo lugar, os de serviços autônomos e de lojas locais. E, por fim, havia os de vendas ou aluguéis de propriedade, como de fazendas, estabelecimentos, bares, residências, centros comerciais, entre outros.

Em sua estrutura, os dois jornais se pareciam muito, o que nos leva a afirmar que o Correio e o grupo que o financiava tomou o espaço econômico e mercadológico que ocupava a Folha por meio de anúncios. No entanto, se os jornais se pareciam em suas estruturas físicas, o Correio se fez, politicamente, muito distinto da Folha. Como já afirmamos, os jornalistas da Folha eram ligados partidariamente a uma corrente nacionalista do PSD e possuíam afinidades com alas nacionalistas. Já os jornalistas do Correio se aproximavam ideologicamente do pensamento udenista. O diretor Benjamin Barbosa havia sido candidato a vereador da cidade pela UDN em 1962, não conseguindo vencer o pleito. 
Ponto interessante do Correio eram as frases de efeito encontradas no final das páginas, algumas de cunho anticomunistas, como: “O comunismo é o último aborto de satanás" (O COMUNISMO..., 1965, p. 2; "Uma sociedade vale, o que valem suas mulheres" (UMA SOCIEDADE..., 1965, p. 1) e "Ocupemos o Brasil antes que outros o façam!” (OCUPEMOS..., 1965, p. 1).

Podemos ver a afinidade com a UDN nas páginas do Correio. Em uma das suas primeiras edições da sua segunda fase, o jornal afirma quais eram essas suas posições e, em nota intitulada "Advertência oportuna" (ADVERTÊNCIA..., 1964, p. 1), anuncia que condena o "comunismo" em nome da "democracia". Nesse sentido, se a Folha apoiava as medidas de Goulart - principalmente as Reformas de Base -, o Correio apoiou sua deposição e a ascensão dos militares. Isso é perceptível logo na primeira edição, em notícia da Marcha da "Família com Deus pela Liberdade" em Ituiutaba, que foi publicada com o título "Marcha da Vitória" (MARCHA..., 1964, p. 1). Na notícia, o jornal se posiciona favorável à deposição de Goulart e anuncia o inimigo, que acabou de ser derrotado: o "perigo comunista". O jornal vivia um clássico paradoxo udenista: afirmava que defendia a democracia, mas apoiava um golpe de Estado. Como nos afirma Benevides (1981), os udenistas acreditavam que ali estava livrando o Brasil de uma futura "ditadura" das esquerdas, contudo, acabaram apoiando o início de uma ditadura de direita.

Também há no jornal um recado levado ao recém-empossado presidente, com o título "Mensagem ao Marechal Castelo Branco", no qual é dito que lhe foi entregue uma carta em mãos, quando estava na cidade vizinha de Uberaba no dia 3 de maio, desejando que tomasse uma direção certa na administração do país, "Tudo por um Brasil forte, livre e feliz" (MENSAGEM..., 1964, p. 1). Também na nota de "Um ano de luta", o jornal comemora tanto o primeiro aniversário do periódico quanto do golpe (UM ANO..., 1965, p. 1).

O jornal se posicionou favorável à tomada do poder local, marcando em suas páginas intimidade com a nova administração do executivo e com os membros da UDN que estiveram à frente das mudanças no Legislativo e Executivo da cidade. Sobre essas deposições, o jornal lançou um editorial com o título "Ituiutaba sob ação do comando militar: Profundas modificações na vida do Executivo e Legislativo do Munícipio" (ITUIUTABA..., 1964, p. 1). Na edição seguinte, no editorial “Ação do Comando Militar em Ituiutaba", foi publicada uma "Palpitante entrevista (exclusiva) concedida a este jornal pelo presidente do diretório municipal da UDN", na qual o então líder udenista responde sobre as mudanças políticas no município, demonstrando a responsabilidade do partido 
nas deposições locais e acusando os políticos locais depostos de mau uso de verbas municipais e subversão (AÇÃO..., 1964, p. 1).

O jornal apoiou a ascensão do novo prefeito do município, sendo que ele foi um dos mantenedores do jornal, além de que a Associação Rural de Ituiutaba, por ele presidida, abrigou a produção do jornal durante seus dois anos de trajetória. O Correio era um jornal conservador em muitos dos seus aspectos, pois defendia o status quo imposto, principalmente, no que diz respeito à propriedade privada. Isso fica bem claro quando o jornal se refere aos comunistas e à revolução. No Correio encontramos a transcrição de um trecho escrito por Ruy Barbosa, em que afirma:

O COMUNISMO não é fraternidade: É a invasão do ódio, entre as classes. Não é a reconciliação dos homens: É a sua exterminação mútua. Não arvora a bandeira do Evangelho: Bane a Deus das almas e reivindicações populares. Não dá tréguas à ordem. Não conhecem a liberdade cristã. Dissolveria a sociedade. Extinguiria a religião. Desumanaria a humanidade. Everteria, subverteria, inverteria a obra do criador (BARBOSA, 1964, p. 2).

Há artigos que denunciam a tentativa de uma "revolução" comunista, tais como “O 'Paraiso' comunista no Brasil”, no qual o jornal afirma que encontrou um documento em que se lia que "se as Fôrças Armadas não se pusessem de pé em defesa das instituições democráticas e da soberania nacional, o Brasil seria transformado em nova Cuba, em simples satélite da Rússia, tal como a Republica do Caribe, Checoslováquia, Hungria, Polónia, Alemanha Oriental e outro" (O "PARAISO”..., 1964, p. 2).

O Correio vivia uma complexa militância anticomunista, pois manifestava que havia um plano arquitetado pela esquerda para tomar o Brasil em 1964, fundando a ditadura do proletariado. Dentro dessa lógica, o jornal viveu uma contradição e uma tensão interna, em que chamava seus escritores e apoiadores de democratas, mas, nas suas linhas, apoiou a derrubada de Goulart em plano nacional e a deposição do prefeito e vereadores em nível local, todos esses eleitos democraticamente. O Correio teve curta duração, chegando ao término em dezembro de 1965.

\section{Considerações finais}

Não era essencial apenas impedir que a Folha continuasse publicando e divulgando as ideias reformistas/nacionalistas nas suas páginas. Era indispensável colocar um novo produto em seu lugar, que faria o mesmo papel de imprensa local da Folha, mas com a missão de porta-voz de outras políticas e como um legitimador da nova ordem 
imposta. Como a política é um jogo de forças, decomposta uma dessas forças, outra toma o seu espaço num todo. E, nesse contexto, ressurge o Correio, ocupando o vácuo político e econômico criado com o fim da Folha.

O Correio de 1964 seguiu um modelo estético parecido com a Folha, entretanto, fazia questão de se diferenciar politicamente, apoiando as medidas persecutórias contra as esquerdas, declarando qualquer fagulha progressista como "comunista". Fazendo isso, o jornal se distanciava do perigo que seu antecessor sofreu: o de ser fechado, além de demonstrar apoio e formar aliança com setores que venceram no processo político. Dessa forma, o jornal se tornou o porta-voz da nova ordem imposta na microrregião, trazendo artigos que tentavam dar legitimidade e confiança ao público leitor sobre os novos administradores que conquistaram o cargo por meios indiretos. Dessa maneira, podemos afirmar que a posição de cada um desses jornais expressa a existência de forças que se opunham ao status quo, bem como de outras coniventes ao novo regime, representando, em suas páginas, a luta de distintas políticas.

\section{Referências}

$13^{\circ}$ SALÁRIO: Prefeitura começou a pagar. Folha de Ituiutaba, Ituiutaba, p. 1, 19 fev. 1964.

A SEMANA Inglesa vem aí!. Folha de Ituiutaba, Ituiutaba, p. 1, 6 fev. 1963.

AÇÃO do Comando Militar em Ituiutaba. Correio do Triângulo, Ituiutaba, p. 1, 7 jun. 1964.

ADVERTÊNCIA oportuna. Correio do Triângulo, Ituiutaba, p. 1, 10 maio 1964.

ALVES, Maria Helena. Estado e oposição no Brasil (1964-1984). Petrópolis: Vozes, 1989.

ARCÊNIO, José. Legislação trabalhista (salário mínimo, etc.) para os trabalhadores municipais. Folha de Ituiutaba, Ituiutaba, p. 1, 2 fev. 1963.

ARQUIVO PÚBLICO MINEIRO (APM). Fundo DOPS/MG, Rolo 049, Pasta 3882.

ASSIS, Francisco. Imprensa do interior: conceitos e contextos. Chapecó:, Argos, 2013.

BANDEIRA, Bruno Taumaturgo. Imprensa e História: o jornal Correio do Triângulo, Ituiutaba/MG, 1959. 2015. Monografia (Curso de Bacharelado em História) - Faculdade de Ciências Integradas do Pontal, Universidade Federal de Uberlândia, Ituiutaba, 2015. 
BARBOSA, Ruy. O comunismo não é fraternidade. Correio do Triângulo, Ituiutaba, p. 2, 19 abr. 1964.

BENEVIDES, Maria Victoria de Mesquita. A UDN e o Udenismo: ambiguidades do liberalismo brasileiro (1945-1965). Rio de Janeiro: Paz e Terra,1981.

CÂMARA aprovou instituição da Semana Inglesa. Folha de Ituiutaba, Ituiutaba, p. 1, 13 mar. 1963.

CAPELATO, Maria Helena Rolim. Imprensa e história do Brasil. São Paulo: Contexto: EDUSP, 1988.

CAPITAL de maus brasileiros depositados no exterior daria para resolver os problemas do País. Folha de Ituiutaba, Ituiutaba, p. 4, 8 dez. 1962.

CHARTIER, Roger. A história cultural: entre práticas e representações. Lisboa: DIFEL, 1990.

CONQUISTOU o PTB (por fim) a prefeitura de Ituiutaba. Folha de Ituiutaba, Ituiutaba, p. 1, 13 out. 1962.

DAMASCENO, Patrícia L. Design de jornais: projeto gráfico, diagramação e seus elementos. Biblioteca Online de Ciências da Comunicação (BOCC), v. 1, p. 1-40, 2013.

DARNTON, Robert. O beijo de Lamourette: mídia, cultura e revolução. São Paulo:

Companhia das Letras, 1990.

DE COMO fazer omelete sem quebrar o ôvo. Folha de Ituiutaba, Ituiutaba, p. 4, 20 jul. 1963.

FAZENDAS de Jango também vão entrar na reforma. Folha de Ituiutaba, Ituiutaba, p. 2, 24 ago. 1963.

GALVES, Marcelo Cheche. Pequena imprensa e poder político: pensando os jornais locais como objeto e fonte de pesquisa. Outros Tempos, São Luís, v. 1, n. 1, p. 66-73, 2004.

HIPPOLITO, Lucia. De raposas e reformistas: o PSD e a experiência democrática brasileira (1945-64). 2. ed. Rio de Janeiro: Nova Fronteira, 2012.

ITUIUTABA quer a Semana Inglesa!. Folha de Ituiutaba, Ituiutaba, p. 1, 23 fev. 1963.

ITUIUTABA sob ação do comando militar: profundas modificações na vida do Executivo e Legislativo do Munícipio. Correio do Triângulo, Ituiutaba, p. 1, 31 maio 1964.

KUCINSKI, Bernardo. Jornalistas e revolucionários: nos tempos da imprensa alternativa. 2. ed. São Paulo: Unesp, 2001. 
LEIS Trabalhistas para o trabalhador Rural. Folha de Ituiutaba, Ituiutaba, p. 1, 30 out. 1963.

LUCA, Tania Regina de. A história dos, nos e por meio dos periódicos. In: PINSKY,

Carla Bassanezi (org.). Fontes históricas. 2. ed. São Paulo: Contexto, 2010. p. 111-153.

MARCHA da Vitória. Correio do Triângulo, Ituiutaba, p. 1, 7 abr. 1964.

MARTINS, Ana Luiza; LUCA, Tania Regina. Extra: imprensa e cidade. São Paulo: Ed. Unesp, 2006.

MENSAGEM ao Marechal Castelo Branco. Correio do Triângulo, Ituiutaba, p. 1, 17 maio 1964.

MOREIRA, Vânia Maria Losada. Nacionalismos e reforma agrária nos anos 50.

Revista Brasileira de História, São Paulo, v. 18, n. 35, 1998.

NECESSÁRIA a reforma agrária, segundo o Censo Agrícola. Folha de Ituiutaba, Ituiutaba, p. 4, 24 ago. 1963.

O "PARAISO” comunista no Brasil. Correio do Triângulo, Ituiutaba, p. 2, 5 jul. 1964.

O COMUNISMO é o último aborto de satanás. Correio do Triângulo, Ituiutaba, p. 2, 27 fev. 1965.

OCUPEMOS o Brasil antes que outros o façam! Correio do Triângulo, Ituiutaba, p. 1, 2 jul. 1965.

OS PRESIDENTES nacionais do PSD, da UDN e do PSP.... Folha de Ituiutaba, Ituiutaba, p. 4, 18 ago. 1962.

PETAGLIA, Thómaz de Aquino. Testemunhos Nacionalistas. Folha de Ituiutaba, Ituiutaba, p. 4, 25 maio 1963.

PREFEITURA de $\mathrm{BH}$ vai pagar $13^{\circ}$ salário a seus servidores. Folha de Ituiutaba, Ituiutaba, p. 1, 5 set. 1962.

REFORMA agrária e gorilas conservadores. Folha de Ituiutaba, Ituiutaba, p. 4, 3 jul. 1963.

REFORMAS: única solução. Folha de Ituiutaba, Ituiutaba, p. 1, 24 dez. 1963.

SANTOS, Ivanildo Francisco dos. Coluna sindical. Folha de Ituiutaba, Ituiutaba, 1963.

SANTOS, Ivanildo Francisco dos. Esclarecimentos sobre o salário mínimo. Folha de Ituiutaba, Ituiutaba, p. 4, 16 jan. 1963. 
SANTOS, Ivanildo Francisco dos. Util e proveitoso trabalho: Procedida a identificação e a entrega de cadernetas profissionais aos trabalhadores de Ituiutaba. Folha de

Ituiutaba, Ituiutaba, p. 4, 22 out. 1962.

TEODORO JÚNIOR, Humberto. Os empréstimos norte-americanos. Folha de Ituiutaba, Ituiutaba, p. 4, 6 abr. 1963.

TRAPOS e retalhos. Folha de Ituiutaba, Ituiutaba, p. 4, 28 ago. 1962.

UM ANO de luta. Correio do Triângulo, Ituiutaba, p. 1, 9 abr. 1965.

UMA SOCIEDADE vale, o que valem suas mulheres. Correio do Triângulo, Ituiutaba, p. 1, 9 abr. 1965 .

VAI começar a sindicalização rural. Folha de Ituiutaba, Ituiutaba, p. 1, 24 ago. 1963.

VOTAÇÃO do Código tributário provocou renúncia do presidente. Folha de Ituiutaba, Ituiutaba, p. 1, 28 ago. 1963.

WEFFORT, Francisco Correa. Jornais são Partidos? Lua Nova, São Paulo, v. 1, n. 2, p. 37-40, set. 1984.

Submetido em: 20/03/2017

Aprovado em: 27/12/2018 